\title{
Physical activity level and depressive symptoms in patients undergoing hemodialysis: a cross-sectional study
}

Nivel de atividade física e sintomas depressivos em pacientes submetidos à hemodiálise: um estudo de corte transversal

Nivel de actividad física y sintomas depresivos en pacientes sometidos a hemodiálisis: un estudio de corte transversal

Cléssyo Tavares de Amorim Cavalcanti', José Cândido de Araújo Filho², Patrícia Érika de Melo Marinho

\begin{abstract}
I This study aimed to evaluate the association between the presence of depressive symptoms and physical activity level (PAL) in patients with chronic kidney disease undergoing hemodialysis (HD). Cross-sectional study comprising 101 patients on HD, mean age $47.4 \pm 12.5$ years. Sociodemographic data, economic, clinical, assessment of depressive symptoms (Beck Depression Scale - BDI), PAL (International Physical Activity Questionnaire - IPAQ), guidance for performing physical activity (PA) and time of HD. The prevalence of sedentary and depressive symptoms was $79.2 \%$ and $39.6 \%$, respectively. Depressive symptoms were observed in $47.5 \%$ of sedentary patients $\left(\chi^{2}=10.029, p=0.002\right)$, the ratio of prevalence of these symptoms five times higher in this group. $68.3 \%$ of patients on HD received no guidance for PA. Under 49 months of hemodialysis treatment, $63.8 \%$ of sedentary $\left(\chi^{2}=3.011, p=0.083\right)$ and $57.5 \%$ of patients with depressive symptoms ( $\left.\chi^{2}=0.100, p=0.752\right)$ already had these features. Although little is known about the relationship between depression and PA among patients undergoing HD, this study found that depressive symptoms were more prevalent among inactive. The results of this study demonstrate that patients undergoing HD have Iow PAL, relative presence of depressive symptoms and high lack of guidance on PA.
\end{abstract}

Keywords I Depression; Exercise; Renal Dialysis.
RESUMOI Este estudo objetivou avaliar a associação entre a presença de sintomas depressivos e o nível de atividade física (NAF) em pacientes renais crônicos submetidos à hemodiálise (HD). Estudo transversal constituído por 101 pacientes sob HD, com idade média de 47,4 $\pm 12,5$ anos. Foram coletados dados sociodemográficos, econômicos, clínicos, avaliação de sintomas depressivos (Escala de Depressão de Beck - BDI), NAF (Questionário Internacional de Atividade Física - IPAQ), orientação para realização da atividade física (AF) e tempo de HD. A prevalência de sedentários e de sintomas depressivos foi 79,2\% e 39,6\%, respectivamente. Os sintomas depressivos foram observados em 47,5\% dos pacientes sedentários ( $\chi^{2}=10,029, p=0,002$ ), sendo a razão de prevalência desses sintomas 5 vezes maior nesse grupo. Dos pacientes sob HD, 68,3\% não receberam orientação para a prática de AF. Abaixo de 49 meses de tratamento hemodialítico, 63,8\% dos sedentários ( $\chi^{2}=3,011, p=0,083$ ) e $57,5 \%$ dos pacientes com sintomas depressivos $\left(\chi^{2}=0,100\right.$, $\mathrm{p}=0,752$ ) já apresentavam essas características. Embora pouco se conheça sobre a relação entre depressão e AF entre pacientes sob HD, o presente estudo verificou que os sintomas depressivos foram mais prevalentes entre os inativos. Os resultados deste estudo demonstram também que pacientes submetidos à HD apresentam baixo NAF, relativa presença de sintomas depressivos e elevada ausência de orientação quanto à realização de AF.

Descritores | Depressão; Exercício; Diálise Renal.

Study carried out in the Santa Casa de Misericórdia do Recife - Recife (PE), Brasil.

'Physical Therapy Course of the Universidade Federal de Pernambuco (UFPE) - Recife (PE), Brazil.

2Programa de Residência Multiprofissional Integrada of the Saúde do Hospital das Clínicas da UFPE - Recife (PE), Brazil. 
RESUMEN I Este estudio tuvo como objetivo evaluar la asociación entre la presencia de síntomas depresivos y el nivel de actividad física (NAF) en pacientes renales crónicos sometidos a hemodiálisis (HD). Estudio transversal constituido por 101 pacientes sob HD, con una edad media de 47,4+12,5 años. Se recogieron datos sociodemográficos, económicos, clínicos, evaluación de síntomas depresivos (Inventario de Depresión de Beck BDI), NAF (Cuestionario Internacional de Actividad Física IPAQ), orientación para la realización de actividad física (AF) y el tiempo de HD. La prevalencia de sedentarios y de síntomas depresivos fue $79,2 \%$ y $39,6 \%$, respectivamente. Se observaron síntomas depresivos en 47,5\% de los pacientes sedentarios $\left(\chi^{2}=10,029, p=0,002\right)$, siendo la proporción de prevalencia de estos síntomas 5 veces mayor en este grupo. De los pacientes sob HD, 68,3\% no recibieron ninguna orientación para la práctica de AF. Menos de 49 meses de tratamiento com hemodiálisis, $63,8 \%$ de los sedentarios ( $\left.\chi^{2}=3,011, p=0,083\right)$ y $57,5 \%$ de los pacientes con síntomas depresivos ( $\chi^{2}=0,100, p=0,752$ ) ya presentaban esas características. Aunque se sabe poco acerca de la relación entre la depresión y AF entre pacientes sob HD, el presente estudio verificó que los síntomas depresivos fueron más prevalentes entre los inactivos. Los resultados de este estudio también demuestran que los pacientes sometidos a HD tienen bajo NAF, relativa presencia de síntomas depresivos y alta falta de orientación sobre la realización de AF.

Palabras clave I Depresión; Ejercício; Diálisis Renal.

\section{INTRODUCTION}

Chronic kidney disease (CKD) is the slowly progressive and irreversible loss of kidney function, in which the body fails to maintain the metabolic and hidroelectrolyte balance ${ }^{1}$.

The number of patients with CKD, worldwide, has increased at an alarming rate, making it a public health problem ${ }^{2,3}$. According to the Brazilian Census of Dialysis ${ }^{4}$, performed in the period from 2000 to 2011, the number of patients on hemodialysis (HD) rose from 42,695 to 91,314, and approximately 85\% of the dialysis patients are covered up by the Sistema Único de Saúde (SUS).

Bonner et al. ${ }^{5}$ stated that individuals with $\mathrm{CKD}$ have symptoms which affect all systems of the body. Among these manifestations, cardiovascular diseases represent an important predictor of morbidity and mortality in these patients ${ }^{6}$. Besides this, the fatigue ${ }^{5}$, the advanced muscle $\operatorname{loss}^{7}$, the decreased functional capacity, the low exercise tolerance ${ }^{8}$, physical inactivity and the depression ${ }^{2}$ are aggravating factors for patients with CKD.

The physical and psychological disorders are conditions which induce patients undergoing $\mathrm{HD}$ into a sedentary lifestyle ${ }^{2}$. Johansen et al. ${ }^{9}$, using a threedimensional accelerometer, observed that the level of physical activity (LPA) was lower in these patients than in healthy sedentary subjects, presenting a $62 \%$ higher risk of death when compared to the non-sedentary ones ${ }^{10}$. This risk, according to Stack et al. ${ }^{11}$, was decreased to 33 or $29 \%$ in patients who would undergo physical exercises 3 to 5 times a week.
Depression is the most common psychiatric disorder in patients undergoing $\mathrm{HD}$ and its prevalence varies between 10 and $60 \%{ }^{12}$. These patients experience multiple losses, including kidney and sexual function, time and mobility, in addition to having fear of death and depending on treatments ${ }^{13}$. However, as the physical aspects of the disease prevail ${ }^{12}$, the diagnosis of depression is not often performed ${ }^{13}$.

According to Condé et al. ${ }^{14}$, depressive symptoms favor lower adherence to physical exercises. In the long term, mental changes and inactivity contribute to low physical activity (PA) in dialysis patients ${ }^{15}$. Moreover, as demonstrated by Knight et al. ${ }^{16}$, the presence of decline in physical function and mental health were independent risk factors for mortality in HD patients, with the possibility of being more aggravating if both would come associated to each other.

Due to the relevance between the PAL and the presence of depressive symptoms (and the lack of studies associating them), the hypothesis of this research is that the presence of depressive symptoms is more prevalent among sedentary patients. The aim of this study was to evaluate the association between depressive symptoms and the PAL in CKD patients undergoing HD.

\section{METODOLOGY}

A cross-sectional study, conducted at the hemodialysis clinic of the Santa Casa de Misericórdia, Recife (PE), in the period from July to December 2012. After clarification, the volunteers gave their 
consent for the participation in the study, according to the Resolution No. 196/96 of the Conselbo Nacional de Saúde. The study was approved by the Ethics Committee in Research (CAAE 01259312.8.0000.5208-12).

The study included patients of both gender, in HD-like renal replacement therapy, aged between 18 and 69 years of age and undergoing hemodialysis for at least 6 months. Patients with neuromusculoskeletal and cardiopulmonary impairments, being considered unfit to carry out PA, with uncorrected visual and/or auditory impairments, cognitive deficits which would prevent them from answering to questionnaires and/or in use of antidepressant medications, were excluded.

The sample size calculation was performed taking as a reference the existing $250 \mathrm{HD}$ patients in the institution at the time of the assessment, being admitted a confidence level of $95 \%$ and using as event frequency (number of patients on HD treatment considered sedentary) the value of $80 \%{ }^{17}$. Assuming a relative error of $10 \%$, the sample consisted of 96 patients. Adding 5\% for possible losses, the final sample consisted of 101 patients. The sample size calculation was performed through the EpiInfo software, version 3.4.3 from 2007.

Initially, sociodemographic and economic data, and guidance as to the practice of PA data were collected; then, the short version of the International Physical Activity Questionnaire (IPAQ) and the Beck Depression Inventory (BDI) were applied.

The instruments were applied only once by a single properly trained examiner, in an interview during the HD session, being assured the confidentiality of the information. The data for the body mass index (BMI), the cause of renal failure and the time on HD were collected directly from the patients' charts.

The economic classification adopted in this study was based on the Economic Classification Criterion of Brazil by the Brazilian Association of Research Companies (Associação Brasileira de Empresas de Pesquisa $)^{18}$.

\section{International Physical Activity Questionnaire}

To identify the PAL, the short form of the IPAQ was used. This questionnaire takes into account the last week, using as a reference the day of the interview, and contains questions about the frequency and duration of light, moderate and vigorous PA. For analysis purposes, the NAF was dichotomized ${ }^{19}$ in: active (very active and active IPAQ categories) and sedentary (sedentary and insufficiently active IPAQ categories.

\section{Beck Depression Inventory}

To assess the presumptive diagnosis of depression, the BDI was used. This tool takes into account the last week and consists of 21 self-assessment questions with 4 alternatives, whose point values range from 0 to 3 , totaling 0-63 points. For purposes of analysis, the presence of depressive symptoms was considered when the score was 17 points or more $^{20}$.

\section{STATISTICAL ANALYSIS}

The data were presented by average \pm standard deviation, absolute values and percentages. Initially, the distribution of normality was performed through the Kolmogorov-Smirnov test. The unpaired Student's $t$-test was used in order to compare the variables age, educational level, BMI and duration of HD between the active and sedentary groups. The Pearson $\chi^{2}$ test was used for the dichotomous variables PAL, depressive symptoms, orientation to the practice of $\mathrm{PA}$ and time of HD. The prevalence ratio for the presence of depressive symptoms was calculated between the active and sedentary individuals. Due to the large variation in the time of $\mathrm{HD}$, for a better representation of the sample, it was stratified on values below and above the average obtained (49 months) and, then, it was performed the verification of the association between it, the PAL and the depressive symptoms. The data were analyzed using the SPSS software, version 18.0 (SPSS Inc., Chicago, IL), and considered significant with $\mathrm{p}<0.05$.

\section{RESULTS}

Of the 250 patients in the clinic, 178 records available at the time of assessment were analyzed and, after verifying the inclusion and exclusion criteria, 101 patients in a HD program participated in the study (Figure 1).

The average age and years of study of the patients were $47.4 \pm 12.5$ years and $8.06 \pm 4.3$ years of age, respectively. The sample consisted of $55.4 \%$ male patients, $56.4 \%$ with a partner and $70.3 \%$ belonging to Class " $\mathrm{C}$ " of the socioeconomic level. Regarding race, $16.8 \%$ of 
them were white and $18.8 \%$ were black, most of them of a brownish color (64.4\%). The most prevalent cause of renal failure was hypertension (55.4\%).

Regarding the length of HD, the average duration of the treatment was $61.5 \pm 50.4$ months and as for the guidelines for the practice of PA, $68.3 \%$ of the individuals reported they had not received guidance in the period.

The prevalence of sedentary individuals and the presence of depressive symptoms in the sample was $79.2 \%$ and $39.6 \%$, respectively. Table 1 shows the sociodemographic, anthropometric and clinical characteristics of the active and sedentary groups.

Regarding the PAL and the presence of depressive symptoms, it was observed that among the physically active patients, $9.5 \%$ of them had depressive symptoms, against $47.5 \%$ of sedentary ones $\left(\chi^{2}=10.029, p=0.002\right)$. The prevalence ratio between active and sedentary ones as for depressive symptoms was 4.99 . As for the orientation to the practice of PA, $72.5 \%$ of the sedentary individuals $\left(\chi^{2}=3.111, \mathrm{p}=0.078\right)$ reported not having received guidance.

Using the average of 49 months duration for the HD treatment, it was observed that, under this period, $63.8 \%$ of the sedentary $\left(\chi^{2}=3.011, \mathrm{p}=0.083\right)$ and $57.5 \%$ of those with depressive symptoms $\left(\chi^{2}=0.100, p=0.752\right)$ already had such characteristics during this period.

\section{DISCUSSION}

The results of this study indicate a high prevalence of physical inactivity and a relative presence of depressive symptoms among patients undergoing HD. The presence of depressive symptoms was higher among inactive ones, with a five times higher prevalence ratio in this group. Regarding the practice of PA, $68.3 \%$ of them reported having received no guidance for such and, in a period under 49 months of HD, more than half of the sedentary patients and of patients with depressive symptoms already featured these characteristics in this period.

The results of this study demonstrated a high prevalence of sedentary patients, which, according Zamojska et $a l .{ }^{15}$, is a common feature of HD patients, possibly due to the loss of strength, muscle atrophy and impaired muscle fibers. Belik et al. ${ }^{8}$ and Medina et al. ${ }^{21}$ rated the PAL of HD patients using the IPAQ and observed a prevalence of $74.5 \%$ and $72.3 \%$, respectively, of sedentary and insufficiently active individuals. Although the studies have used other instruments ${ }^{5,9,15}$ for the assessment of the PAL, the results obtained corroborate the low PAL found in this study.

The conditions which lead patients to depression involve physiological and psychological aspects of treatment ${ }^{22}$, such as HD dependence, fear of death and physical complications of the disease ${ }^{23}$.

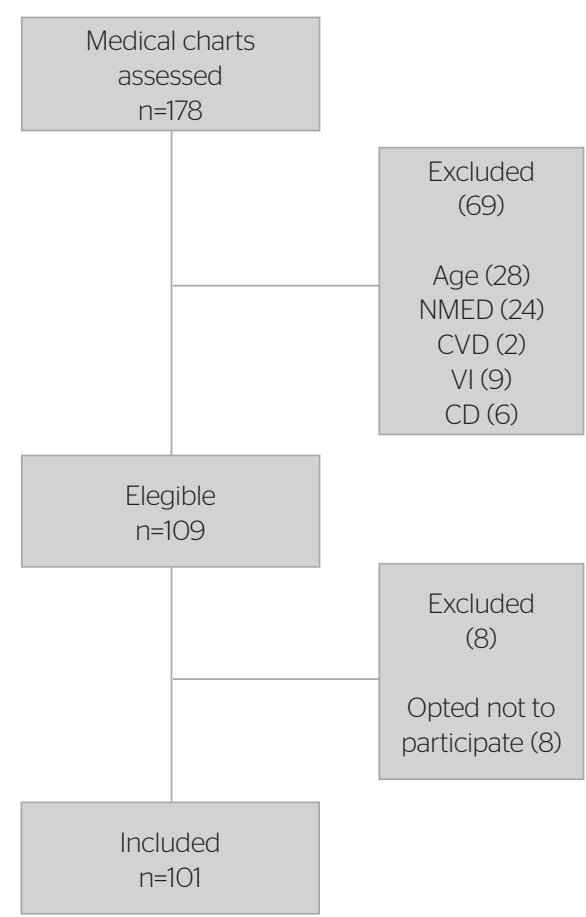

NMED: neuromusculoskeletal disorders; CVD: cardiovascular disorders; VI: visually impaired; $\mathrm{CD}$ : cognitive deficit

Figure 1. Flowchart of the participants in the study

Table 1. Sociodemographic, anthropometric and clinical data of the active and sedentary groups

$\begin{array}{lccc}\text { Variables } & \begin{array}{c}\text { Active IPAQs } \\ (\mathrm{n}=21)\end{array} & \begin{array}{c}\text { Sedentary IPAQs } \\ (\mathrm{n}=80)\end{array} & \mathrm{p} \text {-value } \\ \text { Sociodemographic and } & & & \\ \text { anthropometric } & & & \\ \quad \text { Age } & 45 \pm 11.2 & 48 \pm 12.8 & 0.325 \\ \quad \text { School education (years) } & 8.8 \pm 3.5 & 7.9 \pm 4.5 & 0.372 \\ \quad \text { BMl (kg/m²) } & 22.5 \pm 5.3 & 23.7 \pm 3.8 & 0.280 \\ \text { Clinical } & & & \\ \quad \text { HDT (months) } & 72.1 \pm 49.2 & 58.7 \pm 50.6 & 0.278 \\ \text { Orientation for PA } & & & \\ \quad \text { Yes } & 10(47.6 \%) & 22(27.5 \%) & 0.078 \\ \quad \text { No } & 11(52.4 \%) & 58(72.5 \%) & \\ \text { Depressive symptoms } & & & \\ \quad \text { With symptoms } & 2(9.5 \%) & 38(47.5 \%)^{*} & 0.002 \\ \quad \text { Without symptoms } & 19(90.5 \%) & 42(52.5 \%) & \\ \end{array}$

The data were expressed in mean \pm standard-deviation, absolute value and percentage. IPAQ: International Physical Activity Questionnaire; IMC: índice de massa corporal; HDT: hemodialysis time; PA: physical activity

Significance $p<0.05$; ${ }^{*} \chi^{2}=10.029$; Prevalence Ratio $(P R)=4.99$ 
Castro et $_{\text {al }}{ }^{24}$ found a prevalence of depressive symptoms similar to those obtained in this study; however, other studies using $\mathrm{BDI}^{25,26}$ found different prevalence, possibly because of different characteristics of the studied population, the assessment methods ${ }^{27}$ and the cutoff point of the BDI.

In the general population, depression is related to physical inactivity ${ }^{28}$, but little is known about its occurrence among patients undergoing HD. This study showed that depressive symptoms were more prevalent in the sedentary group. Although this study has not assessed the quality of life, Medina et $a l^{21}$ found significantly lower values on the items of emotional well-being and emotional function of the KDQOL-SF among the sedentary, when compared to very active patients from the IPAQ, denoting the emotional impairment of quality of life among the sedentary. The inclusion of an instrument to detect depressive symptoms may contribute to the greater understanding of the changes among the PAL of these patients.

This study found that a high number of patients received no guidance on the practice of PA, like in the study by Painter et al. ${ }^{29}$. While $98.6 \%$ of U.S.A. nephrologists who were present at the Meeting of the American Society of Nephrology in 2001 have recognized the benefits of PA, only $28.5 \%$ were prescribing exercises to their patients ${ }^{30}$, which draws attention to the investigation of the reasons why this prescription or referral for the practice of PA is not being properly considered. Studies have shown the benefits of PA on the relief of depressive and psychological well-being symptoms ${ }^{31,32}$, with reduction of the BDI score after a program of intra-dialysis aerobic exercises in patients undergoing $\mathrm{HD}^{33}$, as well as the Brazilian Society of Nephrology itself recommends the practice of regular physical activity as a non-pharmacological measure for the control of $\mathrm{CKD}^{34}$.

It was observed, in this study, that most part of the sedentary consisted of subjects who used to be inactive before the four years of treatment. Regarding the depressive symptoms, most of the participants had them prior to this period. Kurella et al. ${ }^{35}$ reported that the PAL decreases sharply with the start of the dialysis and continues decreasing over time, especially in older age groups. The reasons why the patients evaluated in this study presented to be sedentary, or were already sedentary before HD, are unknown; however, these numbers draw attention. Given the relative prevalence of depressive symptoms in the sample evaluated, it is believed that, like Watnick et al. ${ }^{36}$, the possible reasons for depression at the start of the dialysis were changes in lifestyle and the losses caused by dialysis, such as the social role, independence and bodily functions. However, since the reasons were not investigated, it is suggested that further studies addressing these aspects are carried out.

This paper presented as a limitation the need to use instruments which assess the quality of life, especially the characteristics of the disease and its impact, and link it to the PAL and the presence of depressive symptoms. Thus, it is suggested that studies which may elucidate the different aspects of life of patients undergoing $\mathrm{HD}$ are continued.

The present study demonstrated the existence of high prevalence of physical inactivity and the relative presence of depressive symptoms in HD patients, indicating a need for a more comprehensive evaluation of these patients. Physical inactivity should especially be avoided in these patients and it should be prescribed by specialized physical therapists in the area, in order to ensure the quality of life throughout the hemodialysis process.

\section{CONCLUSION}

The results of this study demonstrated that patients with CKD undergoing HD have low PAL and present depressive symptoms, I addition to an elevated absence of guidance as to the realization of PA.

\section{REFERENCES}

1. Böhm J, Monteiro MB, Thomé FS. Efeitos do exercício aeróbio durante a hemodiálise em pacientes com doença renal crônica: uma revisão da literatura. J Bras Nefrol. 2012;34(2):189-94.

2. Reboredo MM, Henrique DMN, Bastos MG, Paula RB. Exercício físico em pacientes dialisados. Rev Bras Med Esporte. 2007;13(6):427-30.

3. Moura RMF, Silva FCR, Ribeiro GM, Souza LA. Efeitos do exercício físico durante a hemodiálise em indivíduos com insuficiência renal crônica: uma revisão. Fisioter Pesq. 2008;15(1):86-91.

4. Sesso RCC, Lopes AA, Thomé FS, Lugon JR, Watanabe Y, Santos DR. Diálise crônica no Brasil-relatório do censo brasileiro de diálise, 2011. J Bras Nefrol. 2012;34(3):272-7.

5. Bonner A, Wellard S, Caltabiano M. The impact of fatigue on daily activity in people with chronic kidney disease. J Clin Nurs. 2010:19(21-22):3006-15. 
6. Mansur HN, Lima JRP, Novaes JS. Nível de atividade física e risco cardiovascular de pacientes com doença renal crônica. J Bras Nefrol. 2007:29(4):209-14

7. Cheema BS, Smith BC, Singh MA. A rationale for intradialytic exercise training as Standard clinical practice in ESRD. Am J Kidney Dis. 2005:45(5):912-6.

8. Stringuetta-Belik F, Shiraishi FG, Silva VRO, Barretti P, Caramori JCT, Bôas PJFV, et al. Maior nível de atividade física associa-se a melhor função cognitiva em renais crônicos em hemodiálise. J Bras Nefrol. 2012;34(4):378-86.

9. Johansen KL, Chertow GM, Ng AV, Mulligan K, Carey S, Schoenfeld PY, et al. Physical activity levels on hemodialysis and healthy sedentary controls. Kidney Int. 2000;57(6):2564-70.

10. O'Hare AM, Tawney K, Bacchetti P, Johansen KL. Decreased survival among sedentary patients undergoing dialysis: results from the dialysis morbidity and mortality study wave 2. Am J Kidney Dis. 2003;41(2):447-54.

11. Stack AG, Molony DA, Rives T, Tyson J, Murthy BV. Association of physical activity with mortality in the US dialysis population. Am J Kidney Dis. 2005;45(4):690-701.

12. Saeed Z, Ahmad AM, Shakoor A, Ghafoor F, Kanwal S. Depression in patients on hemodialysis and their caregivers. Saudi J Kidney Dis Transpl. 2012;23(5):946-52.

13. Chilcot J, Wellsted D, Da Silva-Gane M, Farrington K. Depression on dialysis. Nephron Clin Pract. 2008;108(4):c256-64.

14. Condé SAL, Fernandes N, Santos FR, Chouab A, Mota MMEP, Bastos MG. Declínio cognitivo, depressão e qualidade de vida em pacientes de diferentes estágios da doença renal crônica. J Bras Nefrol. 2010;32(3):242-8.

15. Zamojska S, Szklarek M, Niewodniczy M, Nowicki M. Correlates of habitual physical activity in chronic haemodialysis patients. Nephrol Dial Transplant. 2006;21(5):1323-7.

16. Knight EL, Ofsthun N, Teng M, Lazarus JM, Curhan GC. The association between mental health, physical function, and hemodialysis mortality. Kidney Int. 2003;63(5):1843-51.

17. Longenecker JC, Coresh J, Powe NR, Levey AS, Fink NE, Martin A, et al. Traditional cardiovascular disease risk factors in dialysis patients compared with the general population: the choice study. J Am Soc Nephrol. 2002:13(7):1918-27.

18. Associação Brasileira de Empresas de Pesquisa. Critério de Classificação Econômica Brasil [Internet]. 2012:1-4. [Citado em 16 maio 2013]. Disponível em: www.abep.org/new/Servicos/Download. aspx?id=07

19. Reis HFC, Ladeia AMT, Passos EC, Santos FGO, Wasconcellos LT, Correia LCL, et al. Prevalência e variáveis associadas à inatividade física em indivíduos de alto e baixo nível socioeconômico. Arq Bras Cardiol. 2009;92(3):203-8.

20. Preljevic VT, Østhus TB, Sandvik L, Opjordsmoen S, Nordhus $\mathbb{H}$, Os I, et al. Screening for anxiety and depression in dialysis patients: comparison of the Hospital Anxiety and Depression Scale and the Beck Depression Inventory. J Psychosom Res. 2012;73(2):139-44.
21. Medina LAR, Vanderlei FM, Vanderlei LCM, Torres DB, Padulla SAT, Freitas CEA, et al. Atividade física e qualidade de vida em pacientes com doença renal crônica submetidos à hemodiálise. ConScientiae Saúde. 2010;9(2):212-9.

22. Ferreira RC, Silva Filho CR. A qualidade de vida dos pacientes renais crônicos em hemodiálise na região de Marília, São Paulo. J Bras Nefrol. 2011;33(2):129-35.

23. Moura Junior JA, Souza CAM, Oliveira IR, Miranda RO, Teles C, Moura Neto JA. Risco de suicídio em pacientes em hemodiálise: evolução e mortalidade em três anos. J Bras Psiquiatr. 2008;57(1):44-51.

24. Castro MCM, Silveira ACB, Silva MV, Couto JL, Xagoraris M, Centeno JR, et al. Inter-relações entre variáveis demográficas, perfil econômico, depressão, desnutrição e diabetes mellitus em pacientes em programa de hemodiálise. J Bras Nefrol. 2007:29(3):143-51.

25. Daneker B, Kimmel PL, Ranich T, Peterson RA. Depression and marital dissatisfaction in patients with end-stage renal disease and in their spouses. Am J Kidney Dis. 2001;38(4):839-46.

26. Diefenthaeler EC, Wagner MB, Poli-de-Figueiredo CE, Zimmermann $\mathrm{PR}$, Saitovitch D. Is depression a risk factor for mortality in chronic hemodialysis patients? Rev Bras Psiquiatr. 2008;30(2):99-103.

27. Santos PR. Depression and quality of life of hemodialysis patients living in a poor region of Brazil. Rev Bras Psiquiatr. 2011;33(4):332-7.

28. Roshanaei-Moghaddam B, Katon WJ, Russo J. The longitudinal effects of depression on physical activity. Gen Hosp Psychiatry. 2009;31(4):306-15

29. Painter P, Carlson L, Carey S, Myll J, Paul S. Determinants of exercise encouragement practices in dialysis staff. Nephrol Nurs J. 2004:31(1):67-74

30. Johansen KL, Sakkas GK, Doyle J, Shubert T, Dudley RA. Exercise counseling practices among nephrologists caring for patients on dialysis. Am J Kidney Dis. 2003:41(1):171-8.

31. Painter P. Physical functioning in end-stage renal disease patients: update 2005. Hemodial Int. 2005;9(3):218-35.

32. Johansen KL, Chertow GM, Kutner NG, Dalrymple LS, Grimes BA, Kaysen GA. Low level of self-reported physical activity in ambulatory patients new to dialysis. Kidney Int. 2010;78(11):1164-70.

33. Ouzouni S, Kouidi E, Sioulis A, Grekas D, Deligiannis A. Effects of intradialytic exercise training on health-related quality of life indices in haemodialysis patients. Clin Rehabil. 2009;23(1):53-63.

34. Sociedade Brasileira de Nefrologia; Associação Brasileira de Nutrologia [Internet]. Doença renal crônica (pré-terapia renal substitutiva): tratamento. Projeto Diretrizes. 2011:-24. [Citado em 20 maio 2013]. Disponível em: http://www.projetodiretrizes.org.br/diretrizes10/ doenca_renal_cronica_pre_terapia_renal_substitutiva_tratamento.pdf.

35. Kurella Tamura M, Covinsky KE, Chertow GM, Yaffe K, Landefeld CS, McCulloch CE. Functional status of elderly adults before and after initiation of dialysis. N Engl J Med. 2009;361(16):1539-47.

36. Watnick S, Kirwin P, Mahnensmith R, Concato J. The prevalence and treatment of depression among patients starting dialysis. Am J Kidney Dis. 2003:41(1):105-10. 